\title{
The Correlation Parents Communication To Free Sex Behavior of Adolescent In Sma Negeri 5 Pematangsiantar In 2017
}

\author{
Hanna Sriyanti Saragih \\ Midwifery Department of Poltekkes Kemenkes Medan \\ Email : hannasriyanti80@gmail.com
}

\begin{abstract}
Conflict in the family often occurs due to poor communication between parents and children. Parents who are equally busy, causing the intensity and quality of communication to be very less and not infrequently also cause disputes between them. Through communication, parents should be the primary source of information and educators about free sex behavior on their teenagers. This method aims to analyze the relationship of parent communication (openness, empathy, supportive attitude, positive attitude and equality) to free sex behavior in adolescents in SMA Negeri 5 Pematangsiantar. The type of this research is an analytic survey with cross sectional approach. The population in this study is the students of SMA Negeri 5 Pematangsiantar class XI which amounted to 160 people. A sample of 20 people, taken with cluster sampling technique. Data were obtained by using questioner, analyzed by chi square test at $\alpha=5 \%$. Based on the initial survey conducted, it was found that around $60 \%$ not have free sex. This situation is related to good communication between parents and children, especially communication about sex and good sex education from parents to children who have already obtained children from parents. The conclusions that parents and children are expected to maintain joint communication with free sex behavior of SMA Negeri 5 Pematangsiantar, to students of SMA Negeri 5 Pematangsiantar always improve self-control and be able to withstand a momentary desire or drive that is contrary to inappropriate behavior with social norms and to SMA Negeri 5 Pematangsiantar public still pay attention to students and direct students not to have free sex.
\end{abstract}

Keywords: Parent Communication, Free Sex Behavior, Adolescent

\section{A. PENDAHULUAN}

\section{Latar Belakang}

Komunikasi merupakan istilah yang sangat popular terdengar sekarang ini, meskipun sebenarnya manusia boleh dikatakan hampir tidak mungkin hidup tanpa berkomunikasi. Komunikasi antara orangtua dengan remaja dikatakan berkualitas apabila kedua belah pihak memiliki hubungan yang baik dalam arti bisa saling memahami, saling mengerti, saling mempercayai dan menyayangi satu sama lain. (Amrillah, 2006).

Konflik dalam keluarga sering terjadi karena kurangnya komunikasi yang efektif antara orangtua dan anak. Orangtua yang sama-sama sibuk, menyebabkan kualitas komunikasi menjadi sangat kurang dan tidak jarang pula menimbulkan perselisihan diantaranya. Komunikasi efektif orangtua dan remaja telah ditetapkan sebagai strategi utama dalam meningkatkan perilaku seksual bertanggung jawab dan pengalaman seksual yang minim pada remaja (Burgess, et all, 2005).

Melalui komunikasi, orangtua seharusnya menjadi sumber informasi dan pendidik utama tentang seksualitas bagi remajanya. Namun, orangtua sering menghadapi kesulitan untuk membicarakan masalah seksual kepada remajanya, begitu pun sebaliknya (Kirby, dkk, 2002).

Faktor yang memengaruhi perilaku seksual selain sikap remaja adalah kurangnya informasi mengenai seks peran orang tua yang kurang dan adanya situasi yang mendukung. Untuk itu perlunya informasi tentang pemenuhan kebutuhan remaja melalui pendidikan dan konseling yang tepat (Teguh, 2012).

Komunikasi antara orangtua dan anak mengenai seksualitas merupakan usaha pemberian informasi kepada anak tentang kondisi fisik, hubungan antar manusia, kesehatan seksual dan konsekuensi psikologis yang berkaitan dengan kondisi tersebut, sehingga timbul pengertian dan penghayatan pada remaja tentang identitas seks dalam dirinya yang ditampilkan melalui sikap dan perilakunya sesuai dengan jenis seksual masingmasing sehingga dapat diterima oleh masyarakat (Putri, 2012).

Pembentukan sikap dapat dilakukan oleh orangtua melalui pendidikan seks untuk meningkatkan pengetahuan remaja tentang seksualitas. Remaja yang memiliki kesulitan berkomunikasi dengan orangtuanya tentang masalah seksualitas, cenderung memiliki sikap permisif terhadap hubungan seksual (Nuranti, 2009).

Komunikasi Orangtua dan Perilaku Seksual Remaja Sekolah Menengah Kejuruan di Kota Baturaja Kelas 3 SMK yang berjumlah 50 orang oleh menyebutkan bahwa dalam berkomunikasi tentang hal yang berhubungan dengan perilaku seksual remaja, orangtua paling sering memberikan nasehat tentang larangan untuk tidak melakukan hubungan seksual, namun orangtua tidak memberikan batasan yang jelas dalam pacaran. Remaja mempersepsikan sendiri pesan orangtua, 
bahwa batas yang tidak boleh dilakukan dalam pacaran adalah hubungan seks penelitian yang dilakukan (Sari, 2010).

Remaja masa kini banyak mengalami masalah. Adanya kematangan fisik dan mental tanpa diimbangi percepatan pematangan emosi dan adanya kebebasan yang kian meningkat menyebabkan permasalahan yang dialami remaja menjadi semakin kompleks (Santrock, 2007).

Masalah-masalah akibat seksualitas pada remaja dapat berupa kehamilan pranikah, perilaku seksual remaja yang semakin bebas, dan penularan penyakit seksual. Remaja membutuhkan bimbingan orangtua untuk menghadapi permasalahan yang muncul. Ironisnya, pada saat remaja menghadapi masa peralihan, mulai timbul jarak antara remaja dan orangtua (Collins, dkk, 1993).

Hal tersebut timbul karena pada masa peralihan remaja juga merupakan masa penting dalam hubungan sosialnya. Remaja cenderung untuk lebih dekat dengan teman-teman sebayanya. Sering kali, teman sebaya menjadi pusat bertanya dan berdiskusi dalam menghadapi permasalahan yang dihadapi. Termasuk permasalahan seksualitas yang ingin diketahuinya (Lou \& Chen, 2009).

Remaja menjadi enggan dan malas untuk bertanya. Komunikasi yang terjalin antara orang tua dan remaja menjadi terhambat dan cenderung menjadi tidak efektif. Remaja lebih memilih untuk mempertanyakan dan mendiskusikan hal-hal baru yang terjadi dalam diri mereka dengan teman sebayanya. Padahal, teman sebaya cenderung tidak memiliki pengetahuan yang memadai untuk saling berbagi, terutama informasi mengenai seksualitas. Hal tersebut menjadi sangat riskan karena umumnya pengetahuan remaja tentang masalah seksual masih sangat terbatas, sehingga sering disalahgunakan oleh unsur-unsur yang tidak bertanggungjawab (Subandi, dkk, 1991).

Di Indonesia, terutama dikota-kota besar angka perilaku seks bebas semakin meningkat (Handayani, 2009). BKKBN (2010) menyatakan bahwa sebanyak 51 persen remaja telah melakukan seks pranikah. Dengan kata lain dari 100 remaja, 51 orang sudah tidak perawan. Dari data itu juga disebutkan, penyebaran wilayah remaja yang sudah melakukan seks pranikah terjadi di sejumlah kota besar (Tresnawati, 2012).

Hasil survei SDKI (Survei Demografi Kesehatan Indonesia) 2012 KRR (Kesehatan Reproduksi Remaja) menunjukkan bahwa sekitar 9,3\% atau sekitar 3,7 juta remaja menyatakan pernah melakukan hubungan seksual pranikah, sedangkan hasil SKRRI (Survei Kesehatan Reproduksi Remaja Indonesia) 2007 hanya sekitar 7\% atau sekitar 3 juta remaja. Sehingga selama periode tahun 2007 sampai 2012 terjadi peningkatan kasus remaja yang pernah melakukan hubungan seksual pranikah sebanyak $2,3 \%$.
Pernyataan Deputi Bidang Keluarga Berencana dan Kesehatan Reproduksi (BKKBN) Julianto Witjaksono yang dirilis pada tanggal 12 Agustus 2014 yang mengatakan jumlah remaja yang melakukan hubungan seks di luar nikah mengalami tren peningkatan. Berdasarkan catatan lembaganya, Julianto mengatakan 46 persen remaja indonesia berusia 15-19 tahun sudah berhubungan seks. Data Sensus Nasional bahkan menunjukkan 48-51 persen perempuan hamil adalah remaja (BKKBN, 2014).

Melalui komunikasi yang baik, orangtua dapat mengajak dan menemukan pemahamanpemahaman mengenai seksualitas dan perilaku seksual yang bertanggungjawab pada remaja. Dengan komunikasi orangtua dan anak yang baik, orangtua juga dapat segera menyadari masalahmasalah yang terjadi pada diri anak remajanya dan dapat membantu menyelesaikan masalah tersebut (Wulandari, 2006).

Adanya komunikasi yang baik dengan orangtua diharapkan anak mampu memilah mana yang baik dan mana yang buruk tentang seks untuk dirinya sendiri. Ketika orangtua mendengarkan anak secara aktif, kemampuan anak untuk mengungkapkan perasaan dan isi hatinya dirangsang dan semakin meningkat. Dengan demikian pengetahuan seksualitas dan kualitas komunikasi antara orangtua dan anak mempunyai pengaruh yang penting dalam pembentukan sikap dan perilaku seks bebas remaja (Amrillah, 2006).

Berdasarkan survei awal yang dilakukan peneliti di SMA Negeri 5 Pematangsiantar diperoleh bahwa mereka sekitar 30\% sudah melakukan seks pranikah. Keadaan ini terkait dengan komunikasi orangtua dan anak yang kurang baik terutama komunikasi tentang seksual dan pendidikan seks yang kurang dari orangtua terhadap anak yang kurang di dapatkan anak dari orang tua. Dari 10 orang siswa (laki-laki 4 orang dan perempuan 6 orang) ditemukan 8 orang (80\%) mengatakan bahwa ciuman sudah hal yang biasa bahkan 2 orang (20\%) mengaku sudah pernah melakukan petting.

Hanya sedikit remaja yang berharap bahwa seluk-beluk tentang seks dapat dipelajari dari orangtuanya. Oleh karena itu, remaja mencari berbagai sumber informasi yang mungkin dapat diperoleh, misalnya lewat internet, membahas dengan teman-teman dan buku-buku tentang seks.

Sehingga perilaku seks bebas dapat dicegah sedini mungkin. Penelitian ini bertujuan untuk mengetahui hubungan komunikasi orangtua terhadap perilaku seks bebas pada remaja di SMA Negeri 5 Pematangsiantar.

\section{Rumusan Masalah}

Berdasarkan latar belakang di atas, maka yang menjadi permasalahan adalah bagaimana hubungan komunikasi orang tua terhadap perilaku seks bebas pada remaja di SMA Negeri 5 Pematangsiantar. 


\section{a. Tujuan Umum}

Untuk meningkatkan komunikasi orang tua dengan remaja terhadap perilaku seks bebas.

\section{b. Tujuan Khusus}

1. Untuk mengetahui distribusi frekuensi keterbukaan dalam komunikasi orangtua dan anak terhadap perilaku seks bebas pada remaja.

2. Untuk mengetahui distribusi frekuensi empati dalam komunikasi orangtua dan anak terhadap perilaku seks bebas pada remaja.

3. Untuk mengetahui distribusi frekuensi sikap mendukung dalam komunikasi orangtua dan anak terhadap perilaku seks bebas pada remaja.

4. Untuk mengetahui distribusi frekuensi sikap positif dalam komunikasi orangtua dan anak terhadap perilaku seks bebas pada remaja.

5. Untuk mengetahui distribusi frekuensi kesetaraan dalam komunikasi orangtua dan anak terhadap perilaku seks bebas pada remaja.

\section{Manfaat Penelitian}

1. Supaya Kepala Sekolah SMA Negeri 5 Pematangsiantar dan khususnya guru-guru dapat meningkatkan komunikasi (Keterbukaan, Empati, Sikap mendukung, sikap Positif, Kesetaraan) dengan memberikan perhatian dan memberikan informasi kepada siswa/siswinya tentang perilaku seks bebas.

2. Supaya orangtua siswa lebih meningkatkan komunikasi (Keterbukaan, Empati, Sikap mendukung, sikap Positif, Kesetaraan) mengenai seksualitas terhadap anak untuk menurunkan perilaku seks bebas.

3. Supaya sebagai tambahan pengetahuan, wawasan, pengalaman dan pengembangan ilmu bagi peneliti, khususnya yang terkait dengan perilaku seks bebas.

\section{B. METODE PENELITIAN}

\section{Jenis Penelitian}

Jenis penelitian ini adalah penelitian survei yang bersifat analitik, penelitian yang diarahkan untuk menjelaskan suatu keadaan atau situasi dengan pendekatan cross sectional. Penelitian ini bertujuan untuk menganalisis hubungan komunikasi orang tua terhadap perilaku seks bebas pada remaja di SMA Negeri 5 Pematangsiantar.

\section{Lokasi dan Waktu Penelitian}

Penelitian ini dilaksanakan di SMA Negeri 5 Pematangsiantar. Penelitian ini dilakukan pada bulan April sampai Agustus 2017 di SMA Negeri 5 Pematangsiantar. Dimana selama penelitian dilakukan di SMA Negeri 5 Pematangsiantar, peneliti membagikan kuesioner kepada kelas XI SMA yang terdapat 3 kelas dengan menggabungkan siswa/i dalam satu ruangan yaitu diruangan Aula SMA Negeri 5 Pematangsiantar. Sebelum membagikan kuesioner, peneliti terlebih dahulu menjelaskan kepada siswa/i tentang isi kuesioner tersebut. Jika masih belum mengerti, peneliti mengulang kembali penjelasan tersebut.

\section{Populasi dan Sampel}

Populasi adalah keseluruhan objek penelitian atau objek yang diteliti tersebut (Notoatmodjo, 2012) dalam penelitian ini adalah sebagian siswa SMA Negeri 5 Pematangsiantar kelas XI yang berjumlah 160 orang.

Menurut Notoatmodjo (2012), sampel adalah sebagian yang diambil dari keseluruhan objek yang diteliti dan dianggap mewakili seluruh populasi. Sampel untuk penelitian ini sebanyak 20 responden. Untuk menentukan sampel digunakan tehnik sampling insidental yang dimana teknik ini berdasarkan kebetulan, yaitu siapa saja yang secara kebetulan.

\section{Jenis dan Cara Pengumpulan Data}

Data Primer adalah data yang langsung diperoleh/diambil oleh peneliti. Data yang digunakan dalam penelitian ini adalah data yang diambil langsung menggunakan kuesioner. Data Sekunder adalah data yang tidak langsung diperoleh/diambil oleh peneliti akan tetapi diperoleh dari data yang sudah dikumpulkan oleh pihak lain. Data yang diperoleh dari bagian kesiswaan yaitu data seluruh jumlah siswa SMA Negeri 5 Pematangsiantar.

Pengumpulan data primer dilakukan dengan menggunakan kuesioner untuk mengetahui bagaimana komunikasi orang tua dengan anak tentang perilaku seks bebas. Pengumpulan data dilakukan dengan cara meminta kesedian responden mengisi kuesioner sampai batas sampel terpenuhi. Peneliti terlebih dahulu menjelaskan cara pengisian kuesioner, kemudian menanyakan apakah ada halhal yang tidak dimengerti oleh responden. Apabila ada, maka harus dijelaskan kembali setelah itu hasil kuesioner dikumpulkan kembali.

\section{Metode Pengolahan data Analisis Data}

Data yang telah dikumpulkan selanjutnya diolah dengan langkah-langkah yaitu pengeditan (editing), pengkodean (coding), pemasukan data (entering) dan pembersihan (cleaning).

Analisis data secara univariat dilakukan untuk mendapatkan gambaran distribusi frekuensi responden. Analisa ini digunakan untuk memperoleh gambaran variabel independen (komunikasi orangtua - remaja) dan variabel dependen yaitu perilaku seks bebas pada remaja. Analisis bivariat dilakukan untuk menguji ada tidaknya hubungan komunikasi orangtua-anak terhadap perilaku seks bebas pada remaja di SMA Negeri 5 Pematangsiantar dengan menggunakan statistik uji chi-square kemudian hasilnya dinarasikan.

\section{HASIL PENELITIAN DAN PEMBAHASAN}




\section{HASIL PENELITIAN}

\section{a. Komunikasi Orangtua Anak Keterbukaan}

Untuk melihat keterbukaan, empati, sikap mendukung, sikap positif, dan kesetaraan dalam komunikasi orangtua terhadap perilaku seks bebas pada siswa/i SMA Negeri 5 Pematangsiantar dapat di lihat pada Tabel 1:

Tabel 1.

Distribusi Frekuensi Dalam Komunikasi Orangtua pada Siswa/i SMA Negeri 5 Pematangsiantar

\begin{tabular}{|c|c|c|c|}
\hline $\begin{array}{l}\mathbf{N} \\
\text { o }\end{array}$ & Variabel & $\mathbf{F}$ & $\%$ \\
\hline \multicolumn{4}{|c|}{ Keterbukaan } \\
\hline 1 & Ada keterbukaan & 11 & $55,0 \%$ \\
\hline 2 & Tidak ada keterbukaan & 9 & $45.0 \%$ \\
\hline & Jumlah & 20 & $100 \%$ \\
\hline \multicolumn{4}{|c|}{ Empati } \\
\hline 1 & Empati & 12 & $60,0 \%$ \\
\hline 2 & Tidak Empati & 8 & $40.0 \%$ \\
\hline & Jumlah & 20 & $100 \%$ \\
\hline
\end{tabular}

\begin{tabular}{|c|c|c|}
\hline \multicolumn{3}{|l|}{ Sikap Mendukung } \\
\hline 1 Mendukung & 13 & $65,0 \%$ \\
\hline 2 Tidak Mendukung & 7 & $35,0 \%$ \\
\hline Jumlah & 20 & $100 \%$ \\
\hline \multicolumn{3}{|l|}{ Sikap Positif } \\
\hline $1 \quad$ Bersikap Positif & 11 & $55,0 \%$ \\
\hline 2 Tidak Bersikap Positif & 9 & $45.0 \%$ \\
\hline Jumlah & 20 & $100 \%$ \\
\hline \multicolumn{3}{|l|}{ Kesetaraan } \\
\hline 1 Ada Kesetaraan & 12 & $60,0 \%$ \\
\hline 2 Tidak Ada Kesetaraan & 8 & $40.0 \%$ \\
\hline Jumlah & 20 & 100,0 \\
\hline
\end{tabular}

Berdasarkan tabel di atas, dapat dilihat bahwa :

1. Komunikasi orangtua dan anak mayoritas pada kategori ada keterbukaan sebanyak 11 orang $(55,0 \%)$ dan minoritas pada kategori tidak ada keterbukaan sebanyak 9 orang $(45,0 \%)$.

2. Komunikasi orangtua dan anak mayoritas pada kategori ada empati sebanyak 12 orang $(60,0 \%)$ dan minoritas pada kategori tidak ada empati sebanyak 8 orang $(40,0 \%)$.

3. Komunikasi orangtua dan anak mayoritas pada kategori mendukung sebanyak 13 orang $(65,0 \%)$ dan minoritas pada kategori tidak mendukung sebanyak 7 orang $(35,0 \%)$.

4. Komunikasi orangtua dan anak mayoritas pada kategori bersikap positif sebanyak 11 orang $(55,0 \%)$ dan minoritas pada kategori tidak bersikap positif sebanyak 9 orang $(45,0 \%)$.

5. Komunikasi orangtua dan anak mayoritas pada kategori ada kesetaraan sebanyak 12 orang
$(60,0 \%)$ dan minoritas pada kategori tidak ada kesetaraan sebanyak 7 orang $(40,0 \%)$.

\section{b. Perilaku Seks Bebas}

Untuk melihat perilaku seks bebas pada siswa/i SMA Negeri 5 Pematangsiantar dapat dilihat pada Tabel 2 :

Tabel 2.

Distribusi Frekuensi Perilaku Seks Bebas pada Siswa/i SMA Negeri 5 Pematangsiantar

\begin{tabular}{clcc}
\hline $\begin{array}{l}\text { N } \\
\text { o }\end{array}$ & Perilaku Seks Bebas & F & \% \\
\hline 1 & Baik & 12 & $60,0 \%$ \\
2 & Tidak Baik & 8 & $40.0 \%$ \\
\hline & Jumlah & $\mathbf{2 0}$ & $\mathbf{1 0 0 , 0}$ \\
\hline
\end{tabular}

Berdasarkan tabel di atas, dapat dilihat bahwa kategori perilaku seks bebas pada siswa SMA Negeri 5 Pematangsiantar mayoritas pada kategori baik sebanyak 12 orang $(60,0 \%)$ dan minoritas pada kategori tidak baik sebanyak 8 orang $(40,0 \%)$.

\section{Analisis Bivariat}

Analisis bivariat bertujuan untuk menganalisis hubungan komunikasi orangtua (keterbukaan, empati, sikap mendukung, sikap positif dan kesetaraan), terhadap perilaku seks bebas pada remaja di SMA Negeri 5 Pematangsiantar.

Berdasarkan hasil analisis bivariat antara variabel komunikasi orangtua dengan perilaku seks bebas pada remaja di SMA Negeri 5 Pematangsiantar dapat dilihat pada Tabel 3 :

Tabel 3.

Hubungan Komunikasi Orangtua Terhadap

Perilaku Seks bebas Pada Remaja Di SMA Negeri 5 Pematangsiantar

\section{N Variabel}

$$
\text { Perilaku Seks }
$$$$
\text { Bebas }
$$

Total value

o Baik

\begin{tabular}{|c|c|c|c|c|c|c|c|c|}
\hline \multicolumn{9}{|c|}{ Komunikasi Orangtua } \\
\hline \multirow[t]{5}{*}{ A } & \multicolumn{8}{|l|}{ Keterbukaan } \\
\hline & \multirow[t]{2}{*}{ Ada keterbukaan } & 1 & 90 , & 1 & 9,1 & 1 & 10 & \multirow[t]{4}{*}{0,005} \\
\hline & & 0 & 9 & & & 1 & 0 & \\
\hline & Tidak & 2 & 22 , & 7 & 77 , & 9 & 10 & \\
\hline & keterbukaan & & 2 & & 8 & & 0 & \\
\hline \multirow[t]{5}{*}{$\mathrm{B}$} & \multicolumn{8}{|l|}{ Empati } \\
\hline & \multirow[t]{2}{*}{ Empati } & 1 & 83, & 2 & 16 , & 1 & 10 & \multirow[t]{4}{*}{0,019} \\
\hline & & 0 & 3 & & 7 & 2 & 0 & \\
\hline & \multirow[t]{2}{*}{ Tidak Empati } & 2 & 25 , & 6 & 75 , & 8 & 10 & \\
\hline & & & 0 & & 0 & & 0 & \\
\hline \multirow[t]{5}{*}{$\mathrm{C}$} & \multicolumn{8}{|l|}{ Sikap Mendukung } \\
\hline & \multirow[t]{2}{*}{ Mendukung } & 1 & 84, & 2 & 15 , & 1 & 10 & \multirow[t]{2}{*}{0,004} \\
\hline & & 1 & 6 & & 4 & 3 & 0 & \\
\hline & \multirow[t]{2}{*}{ Tidak mendukung } & 1 & 14, & 6 & 85 , & 7 & 10 & \\
\hline & & & 3 & & 7 & & 0 & \\
\hline
\end{tabular}

D Sikap Positif 


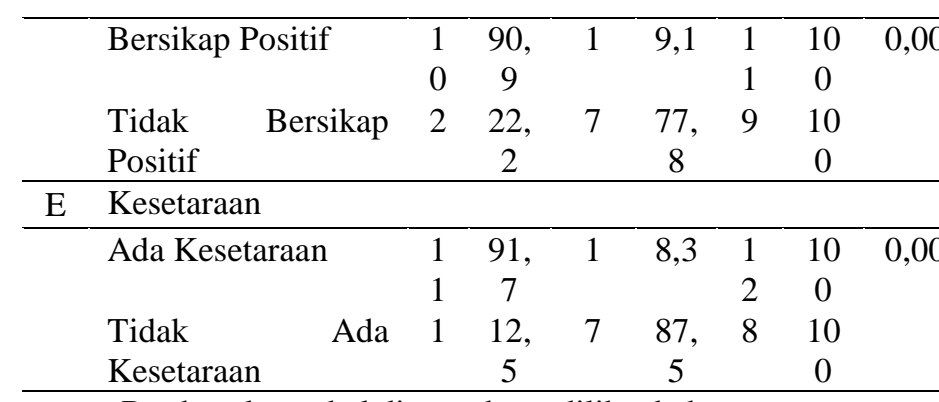

Berdasarkan tabel diatas, dapat dilihat bahwa hasil analisis bivariat antara variabel komunikasi orangtua dan anak terhadap perilaku seks bebas pada remaja di SMA Negeri 5 Pematangsiantar adalah sebagai berikut :

1. Hasil analisis hubungan antara keterbukaan dalam komunikasi orangtua dan anak dengan perilaku seks bebas pada siswa/i SMA Negeri 5 Pematangsiantar diperoleh bahwa dari 11 siswa yang komunikasi orangtua ada keterbukaan ada sebanyak 10 siswa $(90,9 \%)$ dengan periilaku seks bebas yang baik dan dari 9 siswa yang komunikasi orangtua tidak ada keterbukaan ada sebanyak 2 siswa $(22,2 \%)$ dengan perilaku seks baik. Hasil uji statistik chi square menunjukkan bahwa nilai harapan atau expected count dibawah dari $<0,005$ terdapat sebanayak 2 cells (50\%) maka sebaiknya dilakukan dengan uji exact fisher's. Kemudian berdasarkan uji exact fisher's didapat nilai $p=0,005$ maka dapat disimpulkan ada hubungan yang signifikan antara keterbukaan dalam komunikasi orangtua terhadap perilaku seks bebas pada remaja di SMA Negeri 5 Pematangsiantar.

2. Hasil analisis hubungan antara empati dalam komunikasi orangtua terhadap perilaku seks bebas pada siswa/i SMA Negeri 5 Pematangsiantar diperoleh bahwa dari 12 siswa yang komunikasi orangtua ada empati ada sebanyak 10 siswa $(83,3 \%)$ dengan perilaku seks bebas yang baik dan dari 8 siswa komunikasi orangtua yang tidak empati ada sebanyak 2 siswa $(25,0 \%)$ dengan perilaku seks bebas baik. Hasil uji statistik chi square menunjukkan bahwa nilai harapan atau expected count dibawah dari $<0,005$ terdapat sebanayak 3 cells (75\%) maka sebaiknya dilakukan dengan uji exact fisher's. Kemudian berdasarkan uji exact fisher's didapat nilai $p=$ 0,019 maka dapat disimpulkan ada hubungan yang signifikan antara empati dalam komunikasi orangtua terhadap perilaku seks bebas pada remaja di SMA Negeri 5 Pematangsiantar.

3. Hasil analisis hubungan antara sikap mendukung dalam komunikasi orangtua anak terhadap perilaku seks bebas pada siswa/i SMA Negeri 5 Pematangsiantar diperoleh bahwa dari 13 siswa komunikasi orangtua yang mendukung ada sebanyak 11 siswa $(84,6 \%)$
00Æengan perilaku seks bebas yang baik dan dari 7 siswa komunikasi orangtua yang tidak mendukung ada sebanyak 1 siswa (14,3\%) dengan perilaku seks bebas baik. Hasil uji statistik chi square menunjukkan bahwa nilai ,00harapan atau expected count dibawah dari < 0,005 terdapat sebanayak 2 cells (50\%) maka sebaiknya dilakukan dengan uji exact fisher's. Kemudian berdasarkan uji exact fisher's didapat nilai $p=0,004$ maka dapat disimpulkan ada hubungan yang signifikan antara sikap mendukung dalam komunikasi orangtua terhadap perilaku seks bebas pada remaja di SMA Negeri 5 Pematangsiantar.

4. Hasil analisis hubungan antara sikap positif komunikasi orangtua terhadap perilaku seks bebas pada siswa/i SMA Negeri 5 Pematangsiantar diperoleh bahwa dari 11 siswa komunikasi orangtua yang bersikap positif ada sebanyak 10 siswa $(90,9 \%)$ dengan perilaku seks bebas yang baik dan dari 9 siswa komunikasi orangtua yang tidak bersikap positif ada sebanyak 2 siswa $(22,2 \%)$ dengan perilaku seks bebas baik. Hasil uji statistik chi square menunjukkan bahwa nilai harapan atau expected count dibawah dari $<0,005$ terdapat sebanayak 2 cells (50\%) maka sebaiknya dilakukan dengan uji exact fisher's. Kemudian berdasarkan uji exact fisher's didapat nilai $p=$ 0,005 maka dapat disimpulkan ada hubungan yang signifikan antara sikap positif dalam komunikasi orangtua terhadap perilaku seks bebas pada remaja di SMA Negeri 5 Pematangsiantar.

5. Hasil analisis hubungan antara kesetaraan dalam komunikasi orangtua terhadap perilaku seks bebas pada siswa/i SMA Negeri 5 Pematangsiantar diperoleh bahwa dari 12 siswa komunikasi orangtua yang ada kesetaraan ada sebanyak 11 siswa $(91,7 \%)$ dengan perilaku seks bebas yang baik dan dari 8 siswa komunikasi orangtua yang ada kesetaraan ada sebanyak 1 siswa $(12,5 \%)$ dengan perilaku seks bebas baik. Hasil uji statistik chi square menunjukkan bahwa nilai harapan atau expected count dibawah dari < 0,005 terdapat sebanayak 3 cells $(75 \%)$ maka sebaiknya dilakukan dengan uji exact fisher's. Kemudian berdasarkan uji exact fisher's didapat nilai $p=0,001$ maka dapat disimpulkan ada hubungan yang signifikan antara Kesetaraan dalam komunikasi orangtua terhadap perilaku seks bebas pada remaja di SMA Negeri 5 Pematangsiantar.

\section{PEMBAHASAN}

2.1 Hubungan Keterbukaan dalam Komunikasi Orangtua terhadap Perilaku Seks bebas Siswa SMA Negeri 5 Pematangsiantar 
Berdasarkan hasil uji statistik uji chi quare diperoleh prob $=0,005$ artinya ada hubungan komunikasi orangtua (keterbukaan) dengan perilaku seks bebas pada remaja di SMA Negeri 5 Pematangsiantar. Hal ini menunjukan bahwa keterbukaan bermanfaat dalam berkomunikasi antara anak dan orangtua terhadap perilaku seks bebas.

Hasil penelitian ini sesuai dengan hasil penelitian yang dilakukan oleh Mertia,dkk (2011) bahwa kualitas komunikasi orangtua dan anak ialah lebih dari percakapan dan berfokus pada pesan yang disampaikan, apa yang didengar, dan pesan yang dimengerti, dimana proses penyampaian atau pertukaran informasi antara orangtua dan anak dilandasi kepercayaan, keterbukaan, dan hubungan yang baik, sehingga tumbuh sikap percaya anak agar anak dapat menerima dengan baik apa yang disampaikan oleh orangtua.

Menurut asumsi peneliti bahwa keterbukaan orangtua yang diterima oleh anak berhubungan dengan perilaku seks bebas siswa SMA Negeri 5 Pematangsiantar. Karena adanya keterbukaan akan berpengaruh dengan perilaku seks bebas pada anak yang baik. Dengan adanya keterbukaan yang diperoleh, anak akan berusaha untuk lebih mengetahui tentang perilaku seks bebas dan lebih berupaya mencari informasi tentang perilaku seks yang baik. Keterbukaan akan membuat seseorang ingin lebih mengetahui lebih banyak hal yang diperlukan dan lebih tanggap terhadap informasi serta peka melihat perubahan-perubahan yang terjadi.

\subsection{Hubungan Empati dalam Komunikasi Orangtua terhadap Perilaku Seks bebas Siswa SMA Negeri 5 Pematangsiantar}

Berdasarkan hasil uji statistik uji chi quare diperoleh prob $=0,019$ artinya ada hubungan komunikasi orangtua (empati) dengan perilaku seks bebas siswa SMA Negeri 5 Pematangsiantar. Mengacu pada hasil uji tersebut dapat dijelaskan semakin ada empati komunikasi orang tua kepada anak maka akan meningkat perilaku seks bebas kategori baik pada anak.

Hasil Penelitian ini sesuai dengan hasil penelitian yang dilakukan Marriner (1996), selama berinteraksi atau tanya jawab dalam komunikasi kita terlibat dan menghargai lawan bicara dengan kemauan untuk memperhatikan bukan sekedar mendengarkan dan memberikan kesempatan pada orang lain untuk untuk mengutarakan segala topik yang sedang dibicarakan. Dengan adaya simpati dari orangtua, maka orangtua akan merasakan apa yang akan dialami oleh anak. Karena orangtua yang empati terhadap anak mampu memahami motivasi dan, perasaan dan sikap anak serta harapan dan keinginan anak untuk menghindari perilaku seks bebas.
Menurut asumsi peneliti bahwa siswa/i SMA Negeri 5 Pematangsiantar yang merasakan ada empati dari orangtua lebih banyak berperilaku seks bebas baik, hal ini bahwa siswa yang merasakan ada empati dari orangtua dapat menerima komunikasi dari orangtua tentang perilaku seks. Dalam keadaan ini upaya untuk meningkatkan perilaku baik seks bebas pada siswa dapat dilakukan melalui kegiatan penyuluhan tentang seks dan meningkatkan komunikasi yang menunjukkan rasa empati dari orangtua.

\subsection{Hubungan Sikap Mendukung dalam} Komunikasi Orangtua dengan Perilaku Seks bebas Siswa SMA Negeri 5 Pematangsiantar

Berdasarkan hasil uji statistik uji chi quare diperoleh prob $=0,004$ artinya ada hubungan sikap mendukung orangtua dengan perilaku seks bebas pada remaja di SMA Negeri 5 Pematangsiantar. Hal ini menunjukan bahwa sikap mendukung bermanfaat dalam berkomunikasi anatara anak dan orangtua.

Hasil penelitian ini sesuai dengan penelitian yang dilakukan oleh Indrijati (Lestari,2007), semakin meningkat kualitas komunikasi anak dan orangtua maka sikapnya semakin mendukung (menolak atau menjauh) terhadap perilaku seks bebas atau sebaliknya. Jika semakin menurun kualitas komunikasi anak dan orangtua maka sikapnya semakin mendukung (menerima atau positif) terhadap perilaku seks bebas.

Menurut asumsi peneliti bahwa banyak anak yang menyatakan mendapatkan dukungan dari orangtua. Hal ini membuat anak ingin mengetahui perilaku seks bebas. Berdasarkan keadaan ini pemahaman dari orangtua sangat perlu karena anak perlu mendapakan tetap dukungan dari orangtua agar anak berperilaku seks bebas yang baik.

Banyak faktor yang dapat menyebabkan siswa untuk berperilaku seks bebas, dimana sikap mendukung dari orangtua memiliki andil yang besar. Orangtua sebagai motivator yang paling dekat dengan siswa bukan hanya berperan sebagai orangtua saja tetapi juga memiliki peran serta dalam memberikan dukungan kepada anak sejak anak mengetahui seks. Anak yang mendapat dukungan dari orangtua, akan lebih memudahkan anak untuk berperilaku baik pada anak. Hal ini sesuai dengan konsep bahwa orangtua harus mampu mengenali anak atau mampu mengarahkan anak untuk menjauhkan perilaku seks bebas.

\subsection{Hubungan Sikap Positif dalam Komunikasi Orangtua terhadap Perilaku Seks bebas Siswa SMA Negeri 5 Pematangsiantar \\ Berdasarkan hasil uji statistik uji chi quare} diperoleh prob $=0,005$ artinya ada hubungan komunikasi orangtua (sikap positif) dengan perilaku seks bebas. Mengacu pada hasil uji tersebut dapat dijelaskan semakin ada sikap positif dari orangtua 
saat berkomunikasi dengan anak maka akan meningkatkan perilaku baik seks bebas pada kategori baik pada anak.

Hasil penelitian ini sesuai dengan penelitian yang dilakukan oleh M.Teguh (1997) yang mengungkapkan bahwa jika beberapa individu mempunyai perasaan negatif terhadap dirinya dan mengkomunikasikan perasaan tersebut kepada individu lain, maka individu lain ini kemungkinan akan mengembangkan rasa negatif. Sebaliknya jika individu-individu mempunyai perasaan positif terhadap dirinya dan berkeinginan untuk menyampaikan perasaannya kepada individu lain, maka individu lain akan menanggapi dan memperhatikan perasaan positif tadi.

Menurut asumsi peneliti bahwa banyak faktor yang dapat menyebabkan anak untuk berperilaku seks bebas, dimana sikap positif orangtua memiliki andil yang besar. Orangtua sebagai komunikator yang paling dekat dengan anak bukan hanya berperan sebagai orangtua saja, tetapi juga memiliki peran serta dalam memberikan dukungan kepada anak sejak anak berperilaku seks. Mengacu pada hasil uji tersebut dapat dijelaskan semakin ada sikap positif dari orang orangtua maka akan meningkat perilaku baik seks bebas pada anak. Anak yang mendapat sikap positif dari orangtua, akan lebih mudah untuk anak berperilaku seks bebas baik.

\subsection{Hubungan Kesetaraan dalam Komunikasi Orangtua terhadap Perilaku Seks bebas Siswa SMA Negeri 5 Pematangsiantar}

Berdasarkan hasil uji statistik uji chi quare diperoleh prob $=0,001$ artinya ada hubungan komunikasi orangtua (kesetaraan) dengan perilaku seks bebas siswa SMA Negeri 5 Pematangsiantar. Mengacu pada hasil uji tersebut dapat dijelaskan semakin ada kesetaraan dari orangtua saat anak berkomuniksasi dengan anak maka akan meningkatkan perilaku seks bebas kategori baik pada anak.

Hal ini sesuai dengan penelitian yang dilakukan oleh Devito (1997), bahwa dalam setiap situasi, terjadi ketidaksetaraan. Terlepas dari ketidaksetaraan ini, komunikasi akan lebih efektif bila suasananya setara. Artinya, harus ada pengakuan secara diam-diam bahwa kedua pihak sama-sama bernilai dan berharga, dan bahwa masing-masing pihak mempunyai sesuatu yang penting untuk disumbangkan. Dalam suatu hubungan interpersonal yang ditandai oleh kesetaraan, ketidak-sependapatan dan konflik lebih dillihat sebagai upaya untuk memahami perbedaan yang pasti ada daripada sebagai kesempatan untuk menjatuhkan pihak lain, kesetaraan tidak mengharuskan kita menerima dan menyetujui begitu saja semua perilaku verbal dan nonverbal pihak lain. Menurut asumsi peneliti bahwa banyak faktor yang dapat menyebabkan anak untuk berperilaku seks bebas, dimana kesetaraan orangtua memiliki andil yang besar. Orangtua sebagai komunikator yang paling dekat dengan anak bukan hanya berperan sebagai orangtua saja, tetapi juga memiliki peran serta dalam memberikan dukungan kepada anak sejak anak berperilaku seks. Pada penelitian ini banyak anak yang menyatakan orangtua memiliki kesetaraan saat melakukan komunikasi. Hal ini membuat anak berperilaku baik dalam perilaku seks bebas.

\section{D.KESIMPULAN DAN SARAN \\ 1. Kesimpulan}

a. Terdapat hubungan keterbukaan dengan perilaku seks bebas di SMA Negeri 5 Pematangsiantar.

b. Terdapat hubungan empati dengan perilaku seks bebas di SMA Negeri 5 Pematangsiantar.

c. Terdapat hubungan sikap mendukung dengan perilaku seks bebas di SMA Negeri 5 Pematangsiantar.

d. Terdapat hubungan sikap positif dengan perilaku seks bebas di SMA Negeri 5 Pematangsiantar.

e. Terdapat hubungan kesetaraan dengan perilaku seks bebas di SMA Negeri 5 Pematangsiantar.

\section{Saran}

a. Kepada Kepala Sekolah SMA Negeri 5 Pematangsiantar dan khususnya guru-guru agar tetap mempertahankan/ meningkatkan komunikasi (Keterbukaan, Empati, Sikap mendukung, sikap Positif, Kesetaraan) dengan memberikan perhatian dan memberikan informasi kepada siswa/siswinya tentang perilaku seks bebas.

b. Kepada orangtua siswa agar tetap mempertahankan/ meningkatkan komunikasi (Keterbukaan, Empati, Sikap mendukung, sikap Positif, Kesetaraan) mengenai seksualitas terhadap anak untuk menurunkan perilaku seks bebas terutama dalam menunjukan kesetaraan saat berkomunikasi dengan anak.

c. Kepada Penulis agar lebih memperluas pengetahuan, wawasan, pengalaman dan pengembangan ilmu, khususnya yang terkait dengan perilaku seks bebas.

\section{DAFTAR PUSTAKA}

Ali, M., \& Asrori, M. 2014. Psikologi Remaja: Perkembangan Peserta Didik. Jakarta: Bumi Aksara.

Amrillah, A.A., Prasetyaningrum, J., Hertunjung, W.S. 2006. Hubungan antara Pengetahuan Seksualitas dan Kualitas Komunikasi Orang Tua-Anak dengan Perilaku Seksual Pranikah. Indegenous. Jurnal Ilmiah Berkala Psikologi. Vol. 8, No. 1, Mei 2006: 24-34. 
BkkbN. 2010. Seks Bebas Dikalangan Remaja. Diakses tanggal 3 Maret 2015. 2014. Remaja Pelaku Seks Bebas Meningkat. Diakses tanggal 3 Maret 2015.

Burgess V, Dziegielewski SF, Green CE. Improving Comfort about Sex Communication between Parents and Their Adolescents: PracticeBased Research within A Teen Sexuality Group. Brief Treatment and Crisi Intervention. 2005; 5:379-390.

BkkbN, Kemenkes. 2013. Survey Demografi dan Kesehatan Indonesia 2012. Kesehatan Reproduksi Remaja. Diakses Tanggal 13 April 2015.

Dariyo, Agoes. 2004. Perkembangan Remaja. Bogor. PT. Ghalia Indonesia.

Daryanto, Tiffany. 2009. Hubungan antara Religius dengan Perilaku Seks Pranikah pada Mahasiswa Indekost di Malang. Skripsi (tidak diterbitkan). Malang: Universitas Negeri Malang.

Devito, J.A. 1997. The interpersonal communication book. (7th ed). Newyork: Harpers Collins Collage Publishers.

Departemen Kesehatan RI. 2002. Modul Kesehatan Reproduksi Remaja. Jakarta: Departemen Kesehatan RI. . 2007. Modul Pelatihan Pelayanan Kesehatan Peduli Remaja (PKPR). Direktorat Jenderal Bina Kesehatan Masyarakat: Depkes RI: Jakarta.

Erwin, J. Skripsi adi. 2005. Pendidikan Dasar Seks untuk Anak. Yogyakarta: Curiosita.

Fulligni, A. J. \& J.S Eccles. 1993. Perceived ParentChild Relationships and Early Adolescences Orientation Toward Peers. Journal of Developmental Psychology, Vol. 29 No. 4, 622-632

Handayani, S. 2009. Efektivitas Metode Diskusi Kelompok dengan dan Tanpa Fasilitator pada Peningkatan Pengetahuan, Sikap dan Motivasi Remaja tentang Perilaku Seks Pranikah. Diakses dari Berita kedokteran Masyarakat tanggal 25 Maret

Hurlock E. 2004. Psikologi Perkembangan. Jakarta: PT. Gramedia Pustaka

Kumalasari. 2013. Kesehatan Reproduksi Untuk Mahasiswa Kebidanan dan Keperawatan. Jakarta: Salemba Medika.

Kusmiran, Eny. 2012. Kesehatan Reproduksi Remaja dan Wanita. Jakarta: Salemba Medika

Kirby D, Miller BC. Intervention Designed to Promote Parent-Teen Communication about Sexuality. New Direction for Child and Adolescent Development. 2002; 97.

Lestari, S. (2007). Perilaku pacaran remaja ditinjau dari intensitas mengakses situs porno dan komunikasi seksualitas dengan orangtua. Laporan penelitian dosen muda. Surakarta: Fakultas Psikologi Universitas Muhammadiyah Surakarta.

Lou, J., \& Chen, S. 2009. Relationships among sexual knowledge, sexual attitudes, and safe sex behaviour among adolescents: A structural equation model. Journal of Nursing Studies, 6, 1595-1603.

Mappiare, A. (1982). Psikologi Remaja. Surabaya: Usaha Nasional.

Notoadmodjo, S. 2010. Ilmu Kesehatan Masyarakat. Jakarta: Rineka cipta

Nuranti Alifah. 2009. Hubungan antara Komunikasi Orangtua - Remaja dengan Sikap Remaja Terhadap Hubungan Seksual Pranikah di SMA Kabupaten Purworejo, Tesis, Program Pascasarjana, FK UGM, Yogyakarta.

Pangkahila, W. 2005. Seks yang Indah. Jakarta : P.T Kompas Media Nusantara

2007. Membangun Karakter Seksual dan Gender Anak Sejak Dini. www.lk3web.info. (Diakses Tanggal 8 Mei 2008)

Papalia, Diane E, Sally Wendkos \& Ruth Duskin F. 2008. Human Development (Psikologi Perkembangan): Edisi Kesembilan. Jakarta: Kencana Prenada Media Group.

Pieter, Herri Zan. 2012. Pengantar Komunikasi \& Konseling dalam Praktik Kebidanan. Jakarta: Kencana Prenada Media Group.

Pudjono, M. (1993) Perkembangan Seksual Remaja. Laporan Pengabdian Masyarakat (tidak diterbitkan). Yogyakarta: Fakultas Psikologi Universitas Gadjah Mada.

Putri F.A, 2012. Faktor-faktor yang Mempengaruhi Seks Pranikah Pada Remaja SMA di Rengat Kabupaten Indragiri Hulu.

Santrock, J.W. 2007. Remaja, Jilid II (Edisi ke-11). Jakarta: Erlangga.

Sarwono, W.S. 2011. Psikologi Remaja Edisi Revisi. Jakarta: Grafindo Persada

Simanjuntak, B \& Pasaribu, L.I. 1986. Pengantar Psikologi Perkembangan. Bandung: Tarsito.

Subandi, T. Afiatin, \& Avin F.H. 1991. Perkembangan Seksual Remaja dan Kemungkinan Penyimpangannya. Yogyakarta: Fakultas Psikologi Universitas Gadjah Mada.

Teguh, Ahmad, dkk. 2012. Hubungan Pengetahuan, Sikap Terhadap Kesehatan Reproduksi Dengan Praktik Seksual Pranikah Pada Mahasiswi Kebidanan Di Politeknik Kesehatan Depkes Semarang. Semarang : Fakultas Kesehatan Masyarakat Universitas Panegoro.

Trisnawati, F. 2012. Asuhan Kebidanan Jilid I. Jakarta : PT. Prestasi Pustakarya. 
Waylen, A.E. Ness, A. McGovern, P. Wolke, D. Low, N. (2010). Romantic and sexual behavior in young adolescents: Repeated surveys in a population-based cohort. Journal of Early Adolescence, 30, 432-443.

Wiendijarti I. 2011. Komunikasi Interpersonal Orang Tua-Anak dalam Pendidikan Seksual Remaja, Program Studi Ilmu Komunikasi, Universitas Pembangunan Nasional 'Veteran'Yogyakarta, Jurnal Ilmu Komunikasi, Volume 9, Nomor 3, September-Desember 2011.

Wulandari, K, Yuwono, S, Pratisti, W.D. 2006. Perilaku Seksual Ditinjau Dari Kualitas Komunikasi Orangtua-Anak. Indegenous, Jurnal Ilmiah Berkala Psikologi: Vol. 8. No.

Zulkifli, L. 1992. Psikologi Perkembangan. Bandung: Remaja Rosdakarya. 